ORIGINAL RESEARCH PAPER

\title{
PHYSICO-CHEMICAL INVESTIGATION AND ANTIOXIDANT ACTIVITY OF ENCAPSULATED FISH COLLAGEN HYDROLYZATES WITH MALTODEXTRIN
}

\author{
RECEP PALAMUTOĞLU ${ }^{1 *}$, CEMALETTIN SARIÇOBAN² \\ ${ }^{1}$ Afyonkarahisar Health Sciences University, Dörtyol District, 03200 Afyonkarahisar/Turkey \\ ${ }^{2}$ Selçuk University, Alaaddin Keykubat Campus, 42049 Konya, Turkey \\ *Corresponding author: receppalamutoglu@hotmail.com \\ Received on 12 November 2018 \\ Revised on 1 March 2019
}

\begin{abstract}
The aim of the research was to evaluate the effect of the encapsulation process on collagen hydrolysate. Commercial collagen hydrolysate $(\mathrm{CH})$ was spray-dried with maltodextrin (MD) with two different dextrose equivalents (MD12: 10-12 dextrose equivalent (DE) maltodextrin and MD 19: 19-20 DE maltodextrin) and two different core-wall material ratios of 10:90 and 20:80 in pilot scale spray dryer. Four different groups of encapsulated collagen hydrolysate were created such as MD1210 (10\% collagen peptide + 90\% MD12), MD1220 (20\% collagen peptide $+80 \%$ MD12), MD1910 (10\% collagen peptide $+90 \%$ MD19), and MD1920 (20\% collagen peptide + 80\% MD19). Moisture, water activity, hygroscopicity, solubility and antioxidant activity of collagen peptides significantly $(\mathrm{p}<0.01)$ decreased with encapsulation $(\mathrm{p}=0.01)$. The DPPH $(1,1-$ diphenyl-2-picrylhydrazyl) radical scavenging activity analysis results showed that the collagen hydrolysates antioxidant activity was dependent on the dose and the antioxidant activity was significantly decreased by the encapsulation process.
\end{abstract}

Keywords: antioxidant activity, fish collagen, hydrolysates, maltodextrin, spray drying encapsulation

\section{Introduction}

In the past few decades, researchers have focused on bioactive peptides, which are produced by different animal and plant protein sources. Some of them focused on marine products derived from peptides, defined as cobia skin gelatine hydrolysates (Yang et al., 2008), Atlantic herring skin (Pampanin et al., 2012), Korean Rockfish skin (Kim et al., 2011), Grass carp, Nile perch, Nile tilapia skin (Wasswa et al., 2008), surimi processing by-products (Wiriyaphan et al., 2012; Liu et al., 2014), jellyfish collagen hydrolysate (Zhuang et al., 2009; Ding et al., 2011; Zhuang et al., 2012), Gadus morrhua skin collagen hydrolysate (Huo and Zhao, 2009), 
Sphyrna lewini muscle (Wang et al., 2012; Luo et al., 2013), bullfrog skin (Huang et al., 2011), sardinelle by-products (Bougatef et al., 2008, 2010; Nasri et al., 2013), tuna liver (Je et al., 2009), Atlantic salmon skin (Gu et al., 2011), capelin (Amarowicz and Shahidi, 1997), and silver carp (Dong et al., 2008).

Enzymatically hydrolyzed proteins from several sources were reported to have strong antioxidant activities and could be used as antioxidants in food systems. These hydrolyzed proteins have high moisture. Therefore, they could be processed with different methods for preservation. Spray drying is a method used to reduce water activity and formation of capsules. This technique is widely used and its operational costs are very low (Kurozawa et al, 2008).

Collagen is a protein which has a special amino acid composition. It is the most important functional building block of intercellular bond and supporting tissues including the most common protein and cartilage in animals and humans (Seifert, 2004). Collagen is an important component of the extracellular matrix. The denatured collagen is called gelatin and is widely used in foods or pharmaceuticals, photographic film, cosmetics, etc. (Felician et al., 2018). In order to increase gelatin solubility, partially hydrolysed gelatin products were prepared and named collagen hydrolyzate (Shigemura et al., 2011). Enzymatic hydrolysis is used for the production of collagen hydrolyzate from collagenous tissues (bones, hides, fish skin). Proteins with $100 \mathrm{kDa}$ molecular weight were identified at the end of the production of gelatin. Although the same processes are used in the production of collagen hydrolyzates, peptides are formed at the end of the process with a molecular weight of 3-6 kDa. This difference causes the gelling property of the products to be different (Seifert, 2004).

Encapsulation can be used to eliminate the bitterness of protein hydrolysates/ peptides because it coats the bioactive hydrolysates/peptides. The adsorption of bitter peptide to taste receptors could be prevented without altering peptide structure. However, the release mechanism of the encapsulated peptides is still unclear (Mine et al., 2010).

Casein (Rocha et al., 2009), chicken meat protein (Kurozawa et al., 2009, 2011) and shark skin protein (Rodríguez-Díaz et al., 2014) were investigated for protein hydrolysate encapsulation with maltodextrin by using spray drying.

Encapsulation technology was reported to prevent undesirable flavour and bitterness (Rocha et al., 2009; Kurozawa et al., 2011) and to reduce moisture, water activity $\left(\mathrm{a}_{\mathrm{w}}\right)$, hygroscopicity and water solubility of hydrolysates (Rocha et al., 2009; Rodríguez-Díaz et al., 2014). Antioxidant activity of encapsulated hydrolysates is influenced by the presence of maltodextrin (Rodríguez-Díaz et al., 2014).

Bioactive peptides have numerous functions in human health. One of these is the collagen hydrolysate $(\mathrm{CH})$, which has an antioxidative effect (Song and Li, 2017). The encapsulation of bioactive peptides can provide an alternative application to overcome problems associated with direct administration in food (Rao et al., 2016). 
In addition, some protein hydrolysates were found to be very hygroscopic and reactive (Favaro-Trindade et al., 2010).

The aim of this research was to evaluate the influence of encapsulation on collagen hydrolysate by maltodextrin with two different dextrose equivalents and two different cores, which are core-wall material ratios (10:90, 20:80). Some physicochemical and morphological properties and antioxidant capacity of nonencapsulated materials and encapsulated materials were also analyzed.

\section{Materials and Methods}

\section{Materials}

Maltodextrin Maldex 120 and 190 were purchased from Tereos Syral (Aalst, Belgium). The fish collagen hydrolysate (Peptan F 2000 HD) was obtained from Rousseoult Angouléme S.A.S. (Rue de Saint-Michel an Angouléme, Angouléme, France). Fish-hydrolyzed collagen characteristics are presented in Table 1. Analytical grade chemicals and standards were used for analysis (Sigma or Merck) unless otherwise stated.

Table 1. Fish hydrolyzed collagen data

\begin{tabular}{|c|c|c|c|}
\hline Tests & Units & Specifications & Values \\
\hline \multicolumn{4}{|l|}{ Physico-Chemical Limits } \\
\hline $\begin{array}{l}\text { Typical average molecular weight } \\
\text { (Mw) }\end{array}$ & $\mathrm{Da}$ & 2000 & Complian \\
\hline Protein content & $\%$ & $\geq 90$ & Compliant \\
\hline Loss on drying $\left(105^{\circ} \mathrm{C}, 17 \mathrm{~h}\right)$ & $\%$ & $\leq 10$ & 7.2 \\
\hline Bulk density & $\mathrm{g} / \mathrm{cm}^{3}$ & $0.40-0.55$ & 0.50 \\
\hline Residue on ignition $\left(550^{\circ} \mathrm{C}\right)$ & $\%$ & $\leq 2$ & 0.88 \\
\hline Particul size $<425 \mu \mathrm{m}(40$ mesh $)$ & $\%$ & $\geq 95$ & $\geq 95$ \\
\hline Particul size $<75 \mu \mathrm{m}(200$ mesh $)$ & $\%$ & $\leq 15$ & $\leq 15$ \\
\hline Sulfites $\left(\right.$ as $\mathrm{SO}_{2}$ ) & ppm & $\leq 10$ & $\leq 10$ \\
\hline Peroxides $\left(\mathrm{H}_{2} \mathrm{O}_{2}\right)$ & $\mathrm{ppm}$ & $\leq 10$ & $\leq 10$ \\
\hline \multicolumn{4}{|l|}{ Physical \& Chemical Properties } \\
\hline $\mathrm{pH}$ & & & $\begin{array}{c}5.0-6.5 \text { (in } \\
\text { water) }\end{array}$ \\
\hline Physical form & & Powder & \\
\hline Solubility & & $\begin{array}{l}\text { Cold soluble in } \\
\text { water }\end{array}$ & \\
\hline Water solubility & & $\begin{array}{c}\text { Completely } \\
\text { soluble }\end{array}$ & \\
\hline
\end{tabular}

\section{Dispersion preparation}

Dispersions were prepared with $30 \%$ solids (w/w). Solids consisted of maltodextrin (MD12 or MD19) and fish collagen hydrolysate at wall material/core ratios of 90:10 and 80:20 respectively. Powders were dissolved in distilled water and then the samples were homogenized by using a homogenizer (Ultra Turrax T25, Janke 
and Kunkel GmbH \& Co. KG, Staufen, Germany) at $18000 \mathrm{rpm}$ for 2 min at room temperature (Rocha et al., 2009).

\section{Microencapsulation by spray drying}

A laboratory-scale spray dryer (Buchi-B290, Flawil, Switzerland), with a chamber diameter of $16.5 \mathrm{~cm}$, a chamber length of $60 \mathrm{~cm}$ and a standard nozzle with $0.7 \mathrm{~mm}$ was used in microencapsulation experiments. The inlet air temperature and outlet air temperature were maintained at $140 \pm 1^{\circ} \mathrm{C}$ and $80 \pm 0.5^{\circ} \mathrm{C}$, respectively. Microcapsule powders were collected from the bottom of the dryer's cyclone. Powders were stored in an amber bottle in a cool and dry place (Rocha et al., 2009).

\section{Moisture content and $a_{w}$}

Powder moisture, which is contained in encapsulated products, was determined by a moisture analyzer (Ohaus, MB45, USA).

The water activity $\left(a_{w}\right)$ values were analyzed in accordance with the method of Rödel et al. (1975). Water activity meter was used to calculate the encapsulated products $\mathrm{a}_{\mathrm{w}}$ (LabTouch -aw, Novasina AG, Neuheimstrasse Lachen, Switzerland). Approximately $5 \mathrm{~g}$ of homogeneous sample was put in a disposable cup, completely covering the bottom of the cup, and filling not more than half of it. The water activity value was directly measured by a hygrometer with an accuracy of \pm 0.003 .

\section{Hygroscopicity}

The method of Rodríguez-Díaz et al. (2014) was used for determining the hygroscopicity. One $\mathrm{g}$ of sample was placed at $25{ }^{\circ} \mathrm{C}$ in a container with $\mathrm{NaCl}$ saturated solution, and samples were weighed after seven days. Results were expressed as $\mathrm{g}$ moisture/100 g powder.

\section{Dissolution time}

The method of El-Tinay and Ismail (1985) with some modifications was used for the determination of the dissolution time of the powders. In short, $2 \mathrm{~g}$ of powder was added to $50 \mathrm{ml}$ distilled water at $26{ }^{\circ} \mathrm{C}$. The mixture was stirred with a magnetic stirrer (Janke \& Kunkel GmbH \& Co. KG, Staufen, Germany) at 900 rpm. The dissolution time was recorded after the complete dissolution of the material.

\section{Scanning electron microscopy (SEM)}

The microstructure of the spray dried microcapsule powder was observed under SEM (Leo 1430 VP, Leo Electron Microscopy Ltd., Cambridge, UK) coupled with Energy Dispersive X-ray (SEM/EDX) Spectroscopy. The powder was placed on the SEM stub using a double-sided adhesive tape. The microcapsule collagens, coated with a thin layer of gold were immediately analyzed by SEM, operated with an accelerating voltage of $15-20 \mathrm{kV}$.

\section{DPPH radical scavenging activity}

Scavenging DPPH (1,1-diphenyl-2-picrylhydrazyl) free radical of aqueous solutions with different concentrations $(0.5 \%, 1 \%, 2 \%, 3 \%$, and $4 \%)$ of powders was determined by using the method described in the study of Tang et al. (2013), 
with some modifications. An aliquot sample of $2 \mathrm{ml}$ was added to $2 \mathrm{ml}$ of $0.1 \mathrm{mM}$ DPPH in ethanol $(96 \%)$ prepared on a daily basis. The mixture was shaken vigorously for $30 \mathrm{~min}$ and then centrifuged at $5000 \mathrm{rpm}$ for $5 \mathrm{~min}$. The absorbance of the supernatant was then measured using a spectrophotometer (OPTIZENTM POP, Mecasys Co., Daejeon, Korea) at a wavelength of $518 \mathrm{~nm}$. The antioxidant activity of each sample was expressed in percentage inhibition of free radicals.

\section{Statistical analysis}

All experiments were performed in two replicates. One-way analysis of variance (ANOVA) was applied on all the variables, using the SPSS 17 statistical package for Windows (SPSS Inc., Chicago, IL, USA). Duncan's multiple range test $(p<0.05)$ was used to determine the differences between treatment means.

\section{Results and Discussion}

\section{Moisture and water activity}

The moisture content of the encapsulated collagen hydrolysate samples was found to be significantly different from collagen hydrolysate and maltodextrins $(\mathrm{p}<0.01)$. The moisture content of powders was found between $4.15 \pm 0.36 \%$ and $8.42 \pm 0.39 \%$ on dry basis (Table 2). There was no significant difference found between the moisture content of MD1210, MD1910 and MD1920 encapsulated hydrolyzates but their moisture content was significantly lower than the MD1220 group.

Rocha et al. (2009) reported that casein hydrolyzates had significantly higher moisture content than the maltodextrin encapsulated hydrolysates. Also, Kurozawa et al. (2009) concluded in their research that the spray dried chicken meat protein hydrolysate with maltodextrin in different concentrations significantly reduced the moisture content of free hydrolysate. According to Rodríguez-Díaz et al. (2014), a higher solid content of feed solution resulted in a lower moisture content of encapsulated blue sharkskin protein hydrolysate. The water ratio of the solution fed to the spray dryer was found to affect the moisture content of the encapsulated powder. When the solid content of the solution increased, the water content of the powder decreased. Hence, the moisture content of the encapsulated powder is important (Goula and Adamopoulos, 2007). In our study, the moisture content of collagen hydrolysate significantly decreased in accordance to the increase of the concentration of the maltodextrins.

The water activity of powders ranged between $0.11 \pm 0.007$ and $0.36 \pm 0.006$. Because of the moisture content, water activity of collagen hydrolysates was significantly higher than the two different maltodextrins and four different encapsulated collagen hydrolysates $(p<0.01)$. Encapsulated collagen hydrolysates with MD12 had significantly lower $a_{w}$ than the one encapsulated with MD19, and $a_{\mathrm{w}}$ of the encapsulated materials were significantly different from each other. The lowest $\mathrm{a}_{\mathrm{w}}$ was registered for the MD1210 group because MD12 had the lowest moisture content and during encapsulation only $10 \%$ collagen hydrolysate was used. Our results were in agreement with other scientific reports. Encapsulation of casein (Rocha et al., 2009) and bovine liver sarcoplasmic protein hydrolysates (di 
Bernardini et al., 2011) with maltodextrin was found to lower the $a_{w}$ of free hydrolysates. Due to the lower moisture content, and lower $\mathrm{a}_{\mathrm{w}}$ the studied samples could be considered microbiologically stable products.

Table 2. Moisture, water activity, hygroscopicity and water solubility results of powders.

\begin{tabular}{lcccc}
\hline Treatment & Moisture (\%) & Water activity & $\begin{array}{c}\text { Hygroscopicity } \\
\text { (g/100 g powder) }\end{array}$ & $\begin{array}{c}\text { Dissolution } \\
\text { time (sec) }\end{array}$ \\
\hline MD12 & $4.15^{\mathrm{e}} \pm 0.36$ & $0.11^{\mathrm{g}} \pm 0.007$ & $12.13^{\mathrm{c}} \pm 0.04$ & $47.08^{\mathrm{f}} \pm 0.71$ \\
MD19 & $4.71^{\mathrm{d}} \pm 0.17$ & $0.19^{\mathrm{f}} \pm 0.003$ & $12.66^{\mathrm{b}} \pm 0.07$ & $69.28^{\mathrm{cd}} \pm 6.49$ \\
CH & $8.42^{\mathrm{a}} \pm 0.39$ & $0.36^{\mathrm{a}} \pm 0.006$ & $15.01^{\mathrm{a}} \pm 0.17$ & $90.44^{\mathrm{a}} \pm 8.95$ \\
MD1210 & $6.19^{\mathrm{c}} \pm 0.34$ & $0.23^{\mathrm{e}} \pm 0.006$ & $9.86^{\mathrm{f}} \pm 0.29$ & $82.56^{\mathrm{ab}^{\mathrm{b}}} \pm 0.01$ \\
MD1220 & $6.88^{\mathrm{b}} \pm 0.24$ & $0.28^{\mathrm{d}} \pm 0.010$ & $9.61^{\mathrm{g}} \pm 0.12$ & $76.85^{\mathrm{bc}} \pm 8.03$ \\
MD1910 & $5.89^{\mathrm{c}} \pm 0.36$ & $0.30^{\mathrm{c}} \pm 0.005$ & $10.73^{\mathrm{d}} \pm 0.04$ & $57.07^{\mathrm{e}} \pm 2.37$ \\
MD1920 & $6.35^{\mathrm{c}} \pm 0.33$ & $0.35^{\mathrm{b}} \pm 0.004$ & $10.48^{\mathrm{e}} \pm 0.22$ & $63.80^{\mathrm{de}} \pm 7.11$ \\
\hline
\end{tabular}

Values represent the mean \pm standard deviation.

Mean values followed by different superscripts within the same column indicate a statistically significant difference between the mean values $(p<0.01)$.

MD12: Maltodextrin DE10-12, MD19:Maltodextrin DE19-20, CH: Free collagen hydrolysate, MD1210: Collagen hydrolysate encapsulated with MD12 (\%10 CH- \%90 MD12), MD1220: Collagen hydrolysate encapsulated with MD12(\%20 CH- \%80 MD12), MD1910:Collagen hydrolysate encapsulated with MD19 (\%10 CH- \%90 MD19), MD1920: Collagen hydrolysate encapsulated with MD19 (\%20 CH- \%80 MD19).

\section{Hygroscopicity}

Encapsulated collagen hydrolysates presented lower hygroscopicity values in comparison to the free collagen hydrolysate and maltodextrins. The results given in Table 2 showed that collagen hydrolysates had the highest hygroscopicity. Encapsulation of collagen hydrolysates with MD 19 resulted in a significantly higher hygroscopicity than collagen hydrolysates encapsulated with MD 12. Results showed that for all studied powders, hygroscopicity was significantly different from each other.

Rodríguez-Díaz et al. (2014) concluded that hygroscopicity of protein hydrolysate was affected by the maltodextrin concentration. Maltodextrins were used as carrier agent in the present study and the obtained results were in agreement to those presented by Kurozawa et al. (2009) and Rodríguez-Díaz et al. (2014) for blue sharkskin hydrolysate, chicken meat protein hydrolysate and mussel meat hydrolysate, respectively. Rocha et al. (2009) concluded that encapsulated casein hydrolysates hygroscopicity was significantly lower than that of the free hydrolysate. Our results are similar to their conclusion.

\section{Dissolution}

The solubility of powders in distilled water was significantly different among the treatment groups $(\mathrm{p}<0.01)$, as can be observed from Table 2 . Collagen hydrolysate solubility was significantly higher than other powders except MD1210 group. 
According to Rocha et al. (2009), the solubility time of free casein hydrolysates was higher than the encapsulated hydrolysates with maltodextrin (10-12 DE and 19-20 DE). Our results showed similar solubility characteristics.

\section{Morphology of encapsulated collagen hydrolysate}

Scanning electron micrographics of free collagen hydrolysate and encapsulated collagen hydrolysates are showed in Figure 1.

a)

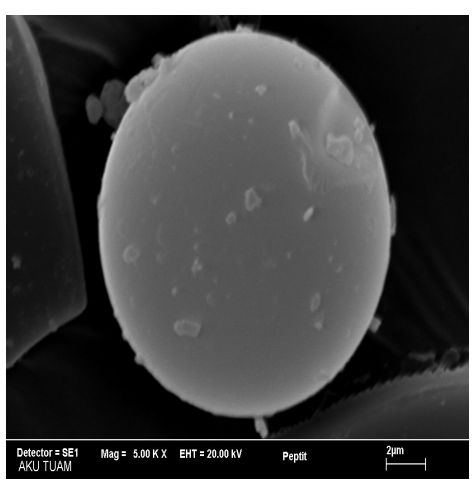

b)

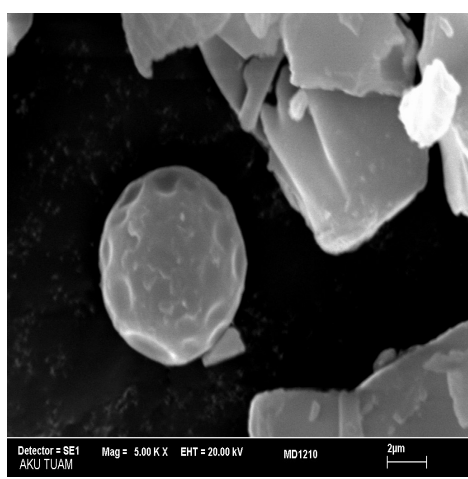

c)
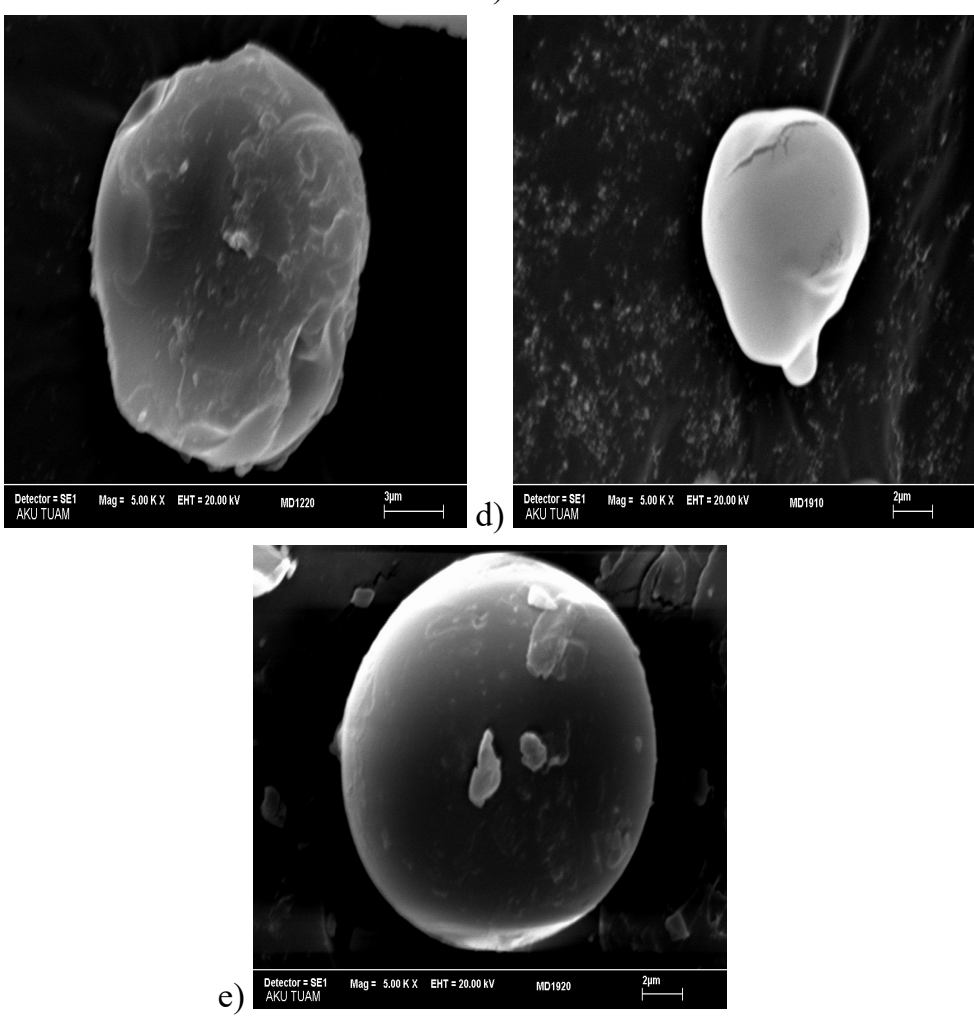

Figure 1. Scanning electron micrographs of free collagen hydrolysate and encapsulated collagen hydrolysates. a: CH (Mag. a; x5000), b: MD1210 (Mag. b; x5000), c: MD1220 (Mag. c; x5000), d: MD1910 (Mag. d; x5000), e: MD1920 (Mag. e; x5000) 
It can be observed that microspheres presented different and various shapes such as smooth-spherical, shrunk-spherical and amorphous. Results were similar to those of Kurozawa et al. (2009) and Rodríguez-Díaz et al. (2014).

As can be seen in Figure 1a the pure collagen hydrolysate showed a spherical shape and smooth particular structure. Some amorphous structures were observed, most probably because of the maltodextrins presence. When collagen hydrolysate was encapsulated with the MD12 molecules the powder showed the spherical shapes but the surfaces were not smooth. This behavior can be explained by the evaporation of moisture during spray drying, causing some shrinkage which resulted in shrunk particles. Kurozawa et al. (2009) concluded that the formation of dents caused adverse effects on the flow characteristics of the encapsulated material. Favaro-Trindade et al. (2010) concluded that the occurrence of the concavities on the surface of the capsules could be associated with the rapid evaporation of the liquid droplets during the spray drying process.

\section{Antioxidant activity}

The antioxidant activity results of encapsulated collagen hydrolysates are given in Table 3. Antioxidant activity of collagen hydrolysate was significantly higher than the other powders and the lowest activity was seen in maltodextrin powders $(p<0.01)$. Encapsulation of collagen hydrolysates with maltodextrin reduced the antioxidant activity. There was no significant differences found in the antioxidant activity of encapsulated collagen hydrolysates.

Table 3. Antioxidant activity (\%) of aquatic solutions of maltodextrins, collagen hydrolysate and encapsulated collagen hydrolysates

\begin{tabular}{lccccc}
\hline \multirow{2}{*}{ Treatments } & $\% 0.5$ & $\% 1$ & $\% 2$ & $\% 3$ & $\% 4$ \\
\cline { 2 - 6 } & $12.98 \pm 1.29^{\mathrm{bcAB}}$ & $10.81 \pm 2.35^{\mathrm{cdB}}$ & $14.88 \pm 1.05^{\mathrm{cdA}}$ & $13.36 \pm 2.30^{\mathrm{cAB}}$ & $14.84 \pm 2.37^{\mathrm{dA}}$ \\
MD12 & $8.87 \pm 0.45^{\mathrm{cC}}$ & $9.65 \pm 0.42^{\mathrm{dC}}$ & $11.83 \pm 0.63^{\mathrm{dB}}$ & $13.97 \pm 1.22^{\mathrm{cA}}$ & $12.99 \pm 1.01^{\mathrm{dAB}}$ \\
MD19 & $26.94 \pm 3.35^{\mathrm{aC}}$ & $36.54 \pm 5.70^{\mathrm{aC}}$ & $53.02 \pm 8.14^{\mathrm{aB}}$ & $68.65 \pm 15.78^{\mathrm{aA}}$ & $78.36 \pm 12.29^{\mathrm{aA}}$ \\
MD & $11.89 \pm 0.09^{\mathrm{bcC}}$ & $12.75 \pm 1.90^{\mathrm{cdC}}$ & $20.86 \pm 3.85^{\mathrm{bcB}}$ & $27.62 \pm 3.36^{\mathrm{bA}}$ & $29.47 \pm 3.73^{\mathrm{cA}}$ \\
MD1220 & $12.45 \pm 1.64^{\mathrm{bcC}}$ & $15.51 \pm 4.38^{\mathrm{bcC}}$ & $22.45 \pm 4.96^{\mathrm{bB}}$ & $29.56 \pm 3.36^{\mathrm{bA}}$ & $33.59 \pm 6.47^{\mathrm{bcA}}$ \\
MD1910 & $15.11 \pm 4.81^{\mathrm{bC}}$ & $18.82 \pm 3.59^{\mathrm{bBC}}$ & $24.30 \pm 4.73^{\mathrm{bAB}}$ & $24.67 \pm 4.97^{\mathrm{bAB}}$ & $30.51 \pm 7.70^{\mathrm{bcA}}$ \\
MD1920 & $14.58 \pm 2.83^{\mathrm{bC}}$ & $18.33 \pm 2.64^{\mathrm{bBC}}$ & $24.92 \pm 6.14^{\mathrm{bB}}$ & $33.75 \pm 4.37^{\mathrm{bA}}$ & $40.27 \pm 7.01^{\mathrm{bA}}$ \\
\hline
\end{tabular}

Values represent the mean \pm standard deviation.

a-c: Mean values followed by different superscripts within the same column indicate a statistically significant difference between the mean values $(p<0.01)$.

A-C: Mean values followed by different superscripts within the same row indicate a statistically significant difference between the mean values $(p<0.01)$.

MD12: Maltodextrin DE12, MD19: Maltodextrin DE19, CH: Free collagen hydrolysate, MD1210: Collagen hydrolysate encapsulated with MD12 (\%10 CH- \%90 MD12), MD1220: Collagen hydrolysate encapsulated with MD12(\%20 CH- \%80 MD12), MD1910:Collagen hydrolysate encapsulated with MD19 (\%10 CH- \%90 MD19), MD1920: Collagen hydrolysate encapsulated with MD19 (\%20 CH- \%80 MD19). 
The values presented in Table 3 show that the antioxidant activity of encapsulated hydrolysates increased with the increase of solution concentration, but no significant differences were found. The highest antioxidant activity of collagen hydrolysate was observed at $4 \%$ aqueous solution $(78.36 \pm 12.29)$ and there was no significant difference found with $3 \%$ concentration (68.65 15.78$)$. According to Kurozawa et al. (2011) the antioxidant activity of spray dried chicken meat hydrolysate was in the range of $38.7 \%$ to $59.4 \%$. In addition to this, they reported that inlet air temperature (from 120 to $200{ }^{\circ} \mathrm{C}$ ) of spray dryer positively affected antioxidant activity.

Rodríguez-Díaz et al. (2014) suggested that the antioxidant capacity of blue sharkskin protein hydrolysates was influenced by the presence of maltodextrin in the samples. This effect was explained by the reducing power of dextrose and byproducts produced during starch hydrolysis. They found that increases in maltodextrin concentration resulted in higher antioxidant capacity, but inlet air temperature did not significantly affect antioxidant capacity because of the temperature range employed $\left(156-190^{\circ} \mathrm{C}\right)$.

\section{Conclusions}

Collagen hydrolysate and maltodextrin powders characteristics were significantly influenced by the encapsulation process. The encapsulation process lowered the moisture content, $\mathrm{a}_{\mathrm{w}}$, hygroscopicity and solubility of collagen hydrolysates by maltodextrin coating. Antioxidant activity of maltodextrin powders significantly increased and activity of free collagen hydrolysate was decreased by the encapsulation process. In this research concentration of the collagen hydrolysate in the spray dryer fed solution was selected at low concentrations. Some researchers showed that feed solution concentration could be increased, in order to improve the antioxidant activity. More studies are needed to find the encapsulation efficiency of protein hydrolysates in model systems and in food systems.

\section{Acknowledgments}

Thanks to TUBITAK Scientist Supporting Department for Recep PALAMUTOĞLU's Ph.D. education. This research is a part of Recep PALAMUTOĞLU's Ph.D. thesis and supported by Selçuk University under grant number of B.A.P/ 14201053. We are grateful to Assist. Prof. Dr. Durmuş SERT for helping us in the encapsulation process. Also, special thanks are given to Rousselot/France for providing fish collagen hydrolysate.

\section{References}

Amarowicz, R., Shahidi, F. 1997. Antioxidant activity of peptide fractions of capelin protein hydrolysates. Food Chemistry, 58(4), 355-359.

Bougatef, A., Nedjar-Arroume, N., Ravallec-Plé, R., Leroy, Y., Guillochon, D., Barkia, A., Nasri, M. 2008. Angiotensin I-converting enzyme (ACE) inhibitory activities of sardinelle (Sardinella aurita) by-products protein hydrolysates obtained by treatment 
with microbial and visceral fish serine proteases. Food Chemistry, 111(2), 350-356.

Bougatef, A., Nedjar-Arroume, N., Manni, L., Ravallec, R., Barkia, A., Guillochon, D., Nasri, M. 2010. Purification and identification of novel antioxidant peptides from enzymatic hydrolysates of sardinelle (Sardinella aurita) by-products proteins. Food Chemistry, 118(3), 559-565.

di Bernardini, R., Rai, D. K., Bolton, D., Kerry, J., O’Neill, E., Mullen, A. M., Harnedy, P., Hayes, M. 2011. Isolation, purification and characterization of antioxidant peptidic fractions from a bovine liver sarcoplasmic protein thermolysin hydrolyzate. Peptides, 32(2), 388-400.

Ding, J.F., Li, Y.Y., Xu, J.J., Su, X.R., Gao, X., Yue, F.P. 2011. Study on effect of jellyfish collagen hydrolysate on anti-fatigue and anti-oxidation. Food Hydrocolloids, 25(5), 1350-1353.

Dong, S., Zeng, M., Wang, D., Liu, Z., Zhao, Y., Yang, H. 2008. Antioxidant and biochemical properties of protein hydrolysates prepared from Silver carp (Hypophthalmichthys molitrix). Food Chemistry, 107(4), 1485-1493.

El-Tinay, A.H., Ismail, I.A. 1985. Effect of some additives and processes on the characteristics of agglomerated and granulated spray-dried Roselle powder. Acta Alimentaria Hungaricae, 14, 283-295.

Favaro-Trindade, C.S., Santana, A.S., Monterrey-Quintero, E.S., Trindade, M.A., Netto, F.M. 2010. The use of spray drying technology to reduce bitter taste of casein hydrolysate. Food Hydrocolloids, 24(4), 336-340.

Felician, F.F., Xia, C., Qi, W., Xu, H. 2018. Collagen from Marine Biological Sources and Medical Applications. Chemistry and Biodiversity, 15(5).

Goula, A.M., Adamopoulos, K.G. 2007. Spray Drying of Tomato Pulp :Effect of Feed Concentration. Drying Technology, 222, 37-41.

Gu, R.Z., Li, C.Y., Liu, W.Y., Yi, W.X., Cai, M.Y. 2011. Angiotensin I-converting enzyme inhibitory activity of low-molecular-weight peptides from Atlantic salmon (Salmo salar L.) skin. Food Research International, 44(5), 1536-1540.

Huang, Y., Li, S., Chuang, T., Chow, C. 2011. In Vitro Evaluation of Antioxidant Activities and Inhibition of ACE Activity by Collagenase-Treated Hydrolysate Derived from Bullfrog Skin. Journal of Food and Drug Analysis, 19(3), 301-308.

Huo, J. X., Zhao, Z. 2009. Study on Enzymatic Hydrolysis of Gadus morrhua Skin Collagen and Molecular Weight Distribution of Hydrolysates. Agricultural Sciences in China, 8(6), 723-729.

Je, J.-Y., Lee, K.-H., Lee, M. H., Ahn, C.-B. 2009. Antioxidant and antihypertensive protein hydrolysates produced from tuna liver by enzymatic hydrolysis. Food Research International, 42(9), 1266-1272.

Kim, H.J., Park, K.H., Shin, J.H., Lee, J.S., Heu, M.S., Lee, D.H., Kim, J.S. 2011. Fractionation and Characterization of Fractions with High Antioxidative Activity from the Gelatin Hydrolysates of Korean Rockfish Sebastes schlegelii Skin. Fisheries and Aquatic Sciences, 14, 168-173.

Kurozawa, L.E., Park, K.J., Hubinger, M.D. 2008. Optimization of the enzymatic hydrolysis of chicken meat using response surface methodology. Journal of Food Science, 73(5), C405-12.

Kurozawa, L. E., Park, K. J., Hubinger, M. D. 2009. Effect of maltodextrin and gum arabic 
on water sorption and glass transition temperature of spray dried chicken meat hydrolysate protein. Journal of Food Engineering, 91(2), 287-296.

Kurozawa, L. E., Park, K. J., Hubinger, M. D. 2011. Spray Drying of Chicken Meat Protein Hydrolysate: Influence of Process Conditions on Powder Property and Dryer Performance. Drying Technology, 29(2), 163-173.

Liu, Y., Li, X., Chen, Z., Yu, J., Wang, F., Wang, J. 2014. Characterization of structural and functional properties of fish protein hydrolysates from surimi processing byproducts. Food Chemistry, 151, 459-465.

Luo, H.Y., Wang, B., Li, Z.R., Chi, C.F., Zhang, Q.H., He, G.Y. 2013. Preparation and evaluation of antioxidant peptide from papain hydrolysate of Sphyrna lewini muscle protein. LWT - Food Science and Technology, 51(1), 281-288.

Mine, Y., Li Chan, E.C., Jiang, B. (2010). Biologically active food proteins and peptides in health. In E. Mine, E. Li-Chan, \& B. Jiang (Eds.), Bioactive Proteins and Peptides as Functional Foods and Nutraceuticals Oxford: Wiley-Blackwell, pp. 5-12.

Nasri, R., Younes, I., Jridi, M., Trigui, M., Bougatef, A., Nedjar-Arroume, N., Dhulster, P., Nasri, M., Karra-Châabouni, M. 2013. ACE inhibitory and antioxidative activities of Goby (Zosterissessor ophiocephalus) fish protein hydrolysates: Effect on meat lipid oxidation. Food Research International, 54(1), 552-561.

Pampanin, D.M., Larssen, E., Provan, F., Sivertsvik, M., Ruoff, P., Sydnes, M.O. 2012. Detection of small bioactive peptides from Atlantic herring (Clupea harengus L.). Peptides, 34(2), 423-426.

Rao, P.S., Bajaj, R.K., Mann, B., Arora, S., Tomar, S.K. 2016. Encapsulation of antioxidant peptide enriched casein hydrolysate using maltodextrin-gum arabic blend. Journal of Food Science and Technology, 53(10), 3834-3843.

Rocha, G.A., Trindade, M.A., Netto, F.M., Favaro-Trindade, C.S. 2009. Microcapsules of a Casein Hydrolysate: Production, Characterization, and Application in Protein Bars. Food Science and Technology International, 15(4), 407-413.

Rödel, W., Panert, H., Leistner, L. 1975. Verbessertes aw-Wert-Messer zur Bestimmung der Wasseraktivitat von Fleisch und Fleisch Waren. Fleischwirtschaft, 4, 557-558.

Rodríguez-Díaz, J.C., Tonon, R.V., Renata V., Hubinger, M.D. 2014. Spray Drying of Blue Shark Skin Protein Hydrolysate: Physical, Morphological and Antioxidant Properties. Drying Technology, 32, 1986-1996.

Seifert, J. 2004. Collagen Hydrolysate and its Biological Value. In M. Teppner (Ed.), Collagen Hydrolysate and its Relationship to Joint Health (1st ed., p. 375). GELITA Health Initiative.

Shigemura, Y., Akaba, S., Kawashima, E., Park, E.Y., Nakamura, Y., Sato, K. 2011. Identification of a novel food-derived collagen peptide, hydroxyprolyl-glycine, in human peripheral blood by pre-column derivatisation with phenyl isothiocyanate. Food Chemistry, 129(3), 1019-1024.

Song, H., Li, B. 2017. Beneficial Effects of Collagen Hydrolysate: A Review on Recent Developments. Biomedical Journal of Scientific \& Technical Research, 1(2), 1-4.

Tang, W.L., Zhang, M., Adhikari, B., Mujumdar, A.S. 2013. Effects of Preparation and Drying Methods on the Antioxidant Activity of Enzymatically Hydrolyzed Porcine Placenta Hydrolysates. Drying Technology, 31(13-14), 1600-1610.

Wang, B., Li, Z.R., Chi, C.F., Zhang, Q.H., Luo, H.Y. 2012. Preparation and evaluation of 
antioxidant peptides from ethanol-solubleproteins hydrolysate of Sphyrna lewini muscle protein. LWT - Food Science and Technology, 36(1), 240-250.

Wasswa, J., Tang, J., Gu, X. 2008. Functional Properties of Grass Carp (Ctenopharyngodon Idella), Nile Perch (Lates Niloticus) and Nile Tilapia (Oreochromis Niloticus) Skin Hydrolysates. International Journal of Food Properties, 11(2), 339-350.

Wiriyaphan, C., Chitsomboon, B., Yongsawadigul, J. 2012. Antioxidant activity of protein hydrolysates derived from threadfin bream surimi byproducts. Food Chemistry, 132(1), 104-111.

Yang, J.I., Ho, H.Y., Chu, Y.J., Chow, C.J. 2008. Characteristic and antioxidant activity of retorted gelatin hydrolysates from cobia (Rachycentron canadum) skin. Food Chemistry, 110(1), 128-136.

Zhuang, Y., Zhao, X., Li, B. 2009. Optimization of antioxidant activity by response surface methodology in hydrolysates of jellyfish (Rhopilema esculentum) umbrella collagen. Journal of Zhejiang University. Science. B, 10(8), 572-579.

Zhuang, Y., Sun, L., Zhang, Y., Liu, G. 2012. Antihypertensive effect of long-term oral administration of jellyfish (Rhopilema esculentum) collagen peptides on renovascular hypertension. Marine Drugs, 10(2), 417-426. 